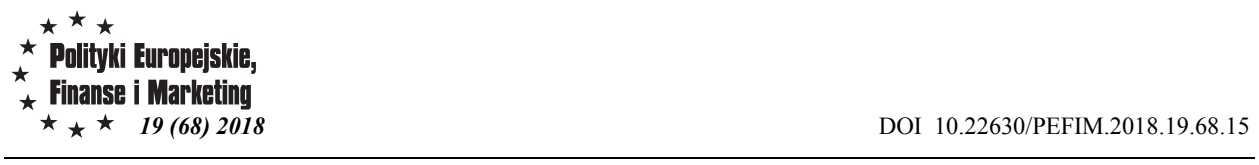

Irena Ozimek

Szkoła Glówna Gospodarstwa Wiejskiego w Warszawie

\title{
Ochrona konsumentów na wybranych rynkach usług w świetle regulacji prawnych i możliwości pozasądowego rozwiązywania sporów konsumenckich
}

\author{
CONSUMER PROTECTION IN SELECTED SERVICE \\ MARKETS IN THE LIGHT OF LEGAL REGULATIONS \\ AND THE POSSIBILITY OF OUT-OF-COURT \\ RESOLUTION OF CONSUMER DISPUTES
}

\begin{abstract}
Celem niniejszego artykutu jest przedstawienie regulacji prawnych, $w$ których ujęto problematykę ochrony konsumentów na rynku wybranych ustug oraz sposoby dochodzenia roszczeń przez konsumentów $w$ przypadku naruszenia ich praw. W ramach badan dokonano analizy danych wtórnych, tj. aktów prawnych, sprawozdań wybranych podmiotów sektorowych (publicznych $i$ niepublicznych) $w$ zakresie pozasqdowego rozwiqzywania sporów między konsumentem a przedsiębiorca, wynikajacych z zawartej z konsumentem umowy. Dokonane analizy wskazuja, że nie zawsze przestrzegane sa prawa konsumentów na rynku ustug. Ponadto, pomimo zwiększajacego się zainteresowania polubownym sposobem rozwiazywania sporów, nadal istnieje konieczność prowadzenia przez różne instytucje $i$ organizacje dziatań informacyjnoedukacyjnych $w$ tym zakresie. Przyczyni się to do wzrostu świadomości istnienia możliwości wykorzystania tego sposobu rozwiazywania sporów, zarówno wśród przedsiębiorców, jak $i$ konsumentów.
\end{abstract}

Slowa kluczowe: ochrona konsumentów, rynek usług, regulacje prawne, dochodzenie roszczeń przez konsumentów, spory konsumenckie, pozasądowe rozwiązywanie sporów konsumenckich

\section{Wstęp}

Współcześnie wzrost poziomu życia społeczeństw jest utożsamiany z serwicyzacją konsumpcji. Usługi w coraz większej mierze są kreatorem nowych potrzeb oraz sposobów ich zaspokajania, a także wyznacznikiem poziomu i jakości życia. Charakteryzują się one dużą zmiennością, odzwierciedlają to liczne przykłady zaniku pewnych usług, bądź tej ujawniania się nowych ze względu na zmieniające się aspiracje konsumentów i ich preferencje. Zmianie ulegają też formy świadczenia usług, czego najlepszym odzwierciedleniem jest postępujący rozwój e-usług.

Należy podkreślić, że obecnie, w dobie znaczącej konkurencji, z jednej strony, przedsiębiorcy zdają sobie sprawę, że zarówno sukces firmy, jak też satysfakcja jej klientów są bezpośrednio powiązane ze zrozumieniem postępowania konsumenta. Skuteczność działania przedsiębiorców na rynku zależy bowiem od umiejętności dostosowania się do oczekiwań i zachowań konsumentów, a także antycypowania zmian 
w tym zakresie, gdyż zmiany te wyznaczają przewidywane kierunki działań marketingowych firmy, a także wpływają na wybór strategii ${ }^{1}$.

$\mathrm{Z}$ drugiej zaś strony, w kontekście dynamicznego rozwoju rynku usług, również przedsiębiorcy powinni dostrzegać znaczenie funkcjonowania systemu ochrony konsumentów i przestrzegać praw konsumentów w tym obszarze. Podkreślić przy tym należy, że konsekwencją istnienia systemu ochrony konsumentów jest przede wszystkim tworzenie regulacji prawnych zabezpieczających interesy nabywców oraz rozwój infrastruktury organizacyjno-funkcjonalnej służącej egzekwowaniu praw konsumenckich. Jak wskazano bowiem już w pierwszym w Polsce programie polityki konsumenckiej na lata 1998-1999, polityka konsumencka powinna być realizowana w następujących płaszczyznach:

- $\quad$ legislacyjnej (tworzenie norm prawnych służących ochronie konsumentów);

- $\quad$ instytucjonalnej (budowanie infrastruktury organizacyjnej);

- $\quad$ inspekcyjno-kontrolnej (badanie przestrzegania praw nabywców);

- $\quad$ sądowej (i przedsądowej), będącej środkiem dochodzenia roszczeń konsumentów;

- informacyjno-edukacyjnej, służącej szerzeniu wiedzy i wzrostowi świadomości konsumenckiej².

Obecnie podkreśla się, że nowoczesna polityka konsumencka UE powinna chronić prawa konsumentów za pomocą regulacji prawnych i gwarantować, że przepisy chroniące konsumentów będą nadążać za zmianami gospodarczymi i społecznymi, (szczególnie na rynku żywności, energii, finansów, transportu i technologii cyfrowych), a także gwarantować, że każdy produkt sprzedawany na jednolitym rynku jest bezpieczny. Istotna jest także pomoc konsumentom $\mathrm{w}$ dokonywaniu świadomego wyboru na podstawie jasnych, precyzyjnych i spójnych informacji (np. podczas zakupów online). Ponadto zadaniem aktualnej polityki konsumenckiej jest szybka i skuteczna pomoc w rozwiązywaniu sporów ze sprzedawcami. Coraz większą uwage przywiązuje się do alternatywnych metod rozwiązywania sporów oraz $\mathrm{z}$ udziałem europejskich centrów konsumenckich ${ }^{3}$.

Stąd też celem niniejszego artykułu jest przedstawienie wybranych regulacji prawnych, w których ujęto problematykę ochrony konsumentów na rynku usług oraz możliwości dochodzenia roszczeń przez konsumentów w przypadku naruszenia ich praw, a także analiza sprawozdań wybranych instytucji w zakresie pozasądowego rozwiązywania sporów między konsumentem a przedsiębiorcą, wynikających z zawartej z konsumentem umowy.

\section{Wybrane regulacje prawne i instytucje z zakresu ochrony konsumentów na rynku usług w Polsce}

W Konstytucji Rzeczypospolitej Polskiej w art. 76 podkreślono, że „Władze publiczne chronią konsumentów, użytkowników i najemców przed działaniami zagrażającymi ich zdrowiu, prywatności i bezpieczeństwu oraz przed nieuczciwymi praktykami rynkowymi”. Ponadto w art. 9 ustawy z dnia 6 marca 2018 r. Prawo

\footnotetext{
${ }^{1}$ A. Wawrzyniak, Modelowanie wieloagentowe jako narzędzie do badania zachowania konsumentów. Zeszyty Naukowe Polityki Europejskie, Finanse i Marketing, 14(63)/2015, s. 135.

${ }^{2}$ Program polityki konsumenckiej na lata 1998-1999. Przegląd Rządowy, 2012, 12, s. 100-109.

${ }^{3}$ Konsumenci. https://europa.eu/european-union/topics/consumers_pl
} 
przedsiębiorców, znalazł się zapis, że ,przedsiębiorca wykonuje działalność gospodarczą zgodnie z zasadami uczciwej konkurencji, poszanowania dobrych obyczajów oraz słusznych interesów innych przedsiębiorców i konsumentów, a także poszanowania oraz ochrony praw i wolności człowieka". Jednocześnie podkreślono, że do działalności gospodarczej polegającej na świadczeniu usług stosuje się odpowiednio niektóre zapisy ustawy z dnia 6 marca 2018 r. o zasadach uczestnictwa przedsiębiorców zagranicznych i innych osób zagranicznych w obrocie gospodarczym na terytorium Rzeczypospolitej Polskiej ${ }^{4}$.

Wiele regulacji prawnych dotyczy ogólnych kwestii związanych z ochroną konsumentów w Polsce, w tym również ochrony konsumentów na rynku usług. Zaliczyć do nich należy ustawę z dnia 16 lutego 2007 r. o ochronie konkurencji i konsumentów ${ }^{5}$, zgodnie $\mathrm{z}$ którą zadania $\mathrm{w}$ dziedzinie ochrony interesów konsumentów w zakresie określonym ustawą oraz odrębnymi przepisami wykonuje Prezes Urzędu Ochrony Konkurencji i Konsumentów. Również istotne są działania w tym zakresie samorządu terytorialnego, na poziomie którego bezpłatne poradnictwo konsumenckie i informację prawną $\mathrm{w}$ zakresie ochrony konsumentów świadczy powiatowy (miejski) rzecznik konsumentów. Zgodnie z zapisem w ustawie o ochronie konkurencji i konsumentów, zadania w zakresie ochrony konsumentów wykonują także organizacje konsumenckie (wśród których należy zwłaszcza wymienić Federację Konsumentów i Stowarzyszenie Konsumentów Polskich) oraz inne instytucje, do których statutowych lub ustawowych zadań należy ochrona interesów konsumentów.

W zakresie kompetencji w obszarze ochrony konsumentów, należy podkreślić rolę Inspekcji Handlowej, funkcjonującej w szczególności na mocy ustawy z dnia 15 grudnia 2000 r. o Inspekcji Handlowej ${ }^{6}$. Do zadań tej inspekcji należy m.in. kontrola legalności i rzetelności działania przedsiębiorców prowadzących działalność gospodarczą w rozumieniu przepisów odrębnych w zakresie produkcji, handlu i usług; prowadzenie postępowania w sprawie pozasąadowego rozwiązywania sporów konsumenckich; organizowanie i prowadzenie stałych sądów polubownych czy też prowadzenie poradnictwa konsumenckiego. Jednakże przepisów tej ustawy nie stosuje się m.in. do: przedsiębiorców wytwarzających energię elektryczną lub ciepło, lub prowadzących hurtowy lub detaliczny handel energią elektryczna, paliwami gazowymi lub ciepłem, lub wykonujących działalność w zakresie przesyłania lub dystrybucji energii elektrycznej lub gazu ziemnego lub przesyłania i dystrybucji ciepła; przedsiębiorców produkujących paliwa; banków oraz prowadzonej przez nie działalności bankowej; ubezpieczeń oraz działalności ubezpieczeniowej; usług pocztowych i telekomunikacyjnych; usług pośrednictwa finansowego; usług informatycznych; usług naukowo-badawczych; usług w zakresie edukacji świadczonych przez podmioty publiczne; usług w zakresie ochrony zdrowia i opieki społecznej.

Wśród tych innych instytucji, warto zwrócić uwagę na istnienie instytucji odnoszących się do poszczególnych sektorów usług. I tak, wśród publicznych podmiotów sektorowych należy wymienić, takie instytucje, jak: Rzecznik Finansowy,

${ }^{4}$ Dz.U. z 2018 r. poz. 649. Wymogi te nie dotyczą jednak świadczenia usług wymienionych w art. 12 niniejszej ustawy.

${ }^{5}$ Tekst jedn.: Dz.U. z 2018 r. poz. 798.

${ }^{6}$ Tekst jedn.: Dz. U. z 2017 r. poz. 1063 z późn. zm. 
Komisja Nadzoru Finansowego, Prezes Urzędu Komunikacji Elektronicznej (UKE), Prezes Urzędu Regulacji Energetyki, Rzecznik Praw Pasażera Kolei działający przy Prezesie Urzędu Transportu Kolejowego.

Rzecznik Finansowy funkcjonuje na mocy ustawy z dnia 5 sierpnia 2015 r. o rozpatrywaniu reklamacji przez podmioty rynku finansowego i o Rzeczniku Finansowym $^{7}$. Do jego zadań należy podejmowanie działań w zakresie ochrony klientów podmiotów rynku finansowego, których interesy reprezentuje. Wśród nich wymienia się m.in.: rozpatrywanie wniosków $\mathrm{w}$ indywidualnych sprawach, wniesionych na skutek nieuwzględnienia roszczeń klienta przez podmiot rynku finansowego $\mathrm{w}$ trybie rozpatrywania reklamacji; opiniowanie projektów aktów prawnych dotyczących organizacji i funkcjonowania podmiotów rynku finansowego; informowanie właściwych organów nadzoru i kontroli o dostrzeżonych nieprawidłowościach w funkcjonowaniu podmiotów rynku finansowego; inicjowanie i organizowanie działalności edukacyjnej i informacyjnej w dziedzinie ochrony interesów klientów podmiotów rynku finansowego.

Z kolei Komisja Nadzoru Finansowego została powołana ustawą z dnia 21 lipca 2006 r. o nadzorze nad rynkiem finansowym ${ }^{8}$. Do jej kompetencji w zakresie ochrony konsumentów należy m.in. stwarzanie możliwości polubownego i pojednawczego rozstrzygania sporów między uczestnikami rynku finansowego, w szczególności sporów wynikających ze stosunków umownych między podmiotami podlegającymi nadzorowi Komisji a odbiorcami usług świadczonych przez te podmioty.

Prezes UKE jest organem regulacyjnym w dziedzinie rynku usług telekomunikacyjnych i pocztowych. Jego kompetencje zostały zawarte w ustawie z dnia 16 lipca 2004 r. Prawo telekomunikacyjne ${ }^{9}$. Istotne jest $\mathrm{w}$ ramach tego Urzędu funkcjonowanie Centrum Informacji Konsumenckiej. Ponadto w działalności UKE podkreślono, że priorytetem jest ochrona interesów konsumentów, w tym m.in. dbanie o jakość usług, a także podejmowanie interwencji w sprawach dotyczących funkcjonowania rynku usług telekomunikacyjnych i pocztowych czy też polubowne rozwiązywanie sporów.

Prezes Urzędu Regulacji Energetyki jest centralnym organem administracji rządowej powołanym na mocy ustawy z 10 kwietnia $1997 \mathrm{r}$. Prawo energetyczne ${ }^{10}$, do realizacji zadań z zakresu regulacji gospodarki paliwami i energią oraz promowania konkurencji. Przy Prezesie Urzędu Regulacji Energetyki funkcjonuje Koordynator do spraw negocjacji.

Prezes Urzędu Transportu Kolejowego (UTK) - to z kolei centralny organ administracji rządowej funkcjonujący na mocy ustawy z dnia 28 marca $2003 \mathrm{r}$. o transporcie kolejowym ${ }^{11}$. Przy Prezesie UTK działa Rzecznik Praw Pasażera Kolei, prowadzący postępowania w sprawie pozasądowego rozwiązywania sporów w sprawach dotyczących zobowiązań umownych, w tym sprzedawcy biletów lub operatora turystycznego, wobec pasażera, wynikających z umów przewozu osób, rzeczy lub zwierząt w transporcie kolejowym oraz w sprawach dotyczących usług świadczonych na

\footnotetext{
${ }^{7}$ Tekst jedn.: Dz.U. z 2017 r. poz. 2270 z późn. zm.

${ }^{8}$ Tekst jedn.: Dz.U. z 2018 r. poz. 621 z późn. zm.

${ }^{9}$ Tekst jedn.: Dz.U. z 2017 r. poz. 1907 z późn. zm. Warto jednakże podkreślić, że Prezes UKE funkcjonuje

także na mocy innych ustaw, por. szerzej: https://bip.uke.gov.pl/podstawy-dzialania-prezesa/ustawy/

${ }^{10}$ Tekst jedn.: Dz.U. z 2018 r. poz. 755.

${ }^{11}$ Tekst jedn.: Dz.U. z 2017 r. poz. 2117 z późn. zm.
} 
rzecz pasażerów przez przewoźnika kolejowego, zarządcę infrastruktury kolejowej, właściciela dworca bądź zarządzającego dworcem.

$\mathrm{Z}$ kolei do niepublicznych podmiotów sektorowych (utworzonych przez przedsiębiorców $\mathrm{z}$ danej branży) zajmujących się ochroną konsumentów na danym rynku usług, zaliczyć należy Bankowy Arbitraż Konsumencki przy Związku Banków Polskich; Stowarzyszenie Praw Pasażerów Przyjazne Latanie; Izbę Gospodarki Elektronicznej.

$\mathrm{W}$ relacji konsument - usługodawca istotne jest również przestrzeganie przez przedsiębiorców zasad wynikających $\mathrm{z}$ ustawy $\mathrm{z}$ dnia 23 sierpnia 2007 r. o przeciwdziałaniu nieuczciwym praktykom rynkowym ${ }^{12}$. Zgodnie $\mathrm{z}$ zapisem tej ustawy Rzecznik Praw Obywatelskich; Rzecznik Finansowy; krajowa lub regionalna organizacja, której celem statutowym jest ochrona interesów konsumentów oraz powiatowy (miejski) rzecznik konsumentów, mogą wystąić $\mathrm{z}$ roszczeniami dotyczącymi zaniechania tej praktyki; złożenia jednokrotnego lub wielokrotnego oświadczenia odpowiedniej treści $\mathrm{i}$ w odpowiedniej formie; czy też zasądzenia odpowiedniej sumy pieniężnej na określony cel społeczny związany ze wspieraniem kultury polskiej, ochroną dziedzictwa narodowego lub ochroną konsumentów.

Ponadto, prowadząc działalność usługową, przedsiębiorca powinien również przestrzegać ustawy z dnia 16 kwietnia 1993 r. o zwalczaniu nieuczciwej konkurencji ${ }^{13}$; bowiem przedsiębiorcy prowadzący działalność gospodarczą zobowiązani są do przestrzegania reguł uczciwości i poszanowania interesów swoich konkurentów, jak i klientów. Świadcząc usługi, przedsiębiorca nie powinien również zapominać o istotnych zapisach z punktu widzenia ochrony konsumentów, w tym m.in. ustawy z dnia 30 maja 2014 r. o prawach konsumenta ${ }^{14}$, ustawy z dnia 9 maja 2014 r. o informowaniu o cenach towarów i usług ${ }^{15}$ czy też ustawy $\mathrm{z}$ dnia 1 lipca 2002 r. o świadczeniu usług drogą elektroniczną ${ }^{16}$ oraz ustawy z dnia 23 kwietnia 1964 r. Kodeks cywilny ${ }^{17}$.

\section{Skargi i zapytania konsumentów dotyczące jakości oferowanych usług kierowane do powiatowych (miejskich) rzeczników konsumentów}

Jakość stanowi decydujący czynnik o sukcesie rynkowym przedsiębiorstwa. Odnosi się to również do przedsiębiorcy działającego na rynku usług, gdzie występuje niezwykle silna konkurencja oraz zróżnicowanie oczekiwań usługobiorców. Koniecznym staje się więc szukanie instrumentów walki konkurencyjnej o klienta. Przedsiębiorstwa usługowe powinny m.in. podejmować świadome działania zgodnie z orientacją marketingową (uwzględniającą potrzeby aktualnego i potencjalnego klienta). Jakość świadczonych usług jest bowiem równocześnie solidną podstawą do budowania trwałych więzi z klientami ${ }^{18}$.

\footnotetext{
${ }^{12}$ Dz.U. z 2007 r. Nr 171, poz. 1206.

${ }^{13}$ Tekst jedn.: Dz.U. z 2003 r. Nr 153, poz. 1503 z późn. zm.

${ }^{14}$ Tekst jedn.: Dz.U. z 2017 r. poz. 683.

${ }^{15}$ Dz.U. z 2014 r. poz. 915 z późn. zm.

${ }^{16}$ Tekst jedn.: Dz.U. z 2017 r. poz. 1219.

${ }^{17}$ Tekst jedn.: Dz.U. z 2017 r. poz. 459 z późn. zm.

${ }^{18}$ M. Stoma, Modele i metody pomiaru jakości usług. Q\&R Polska Sp. z o.o., Lublin 2012, s. 7-8.
} 
Według sprawozdania powiatowych rzeczników konsumentów za rok 2016, w pierwszej kategorii spraw dotyczącej usług (206 584) najwięcej spraw, bo 54646 dotyczyło usług telekomunikacyjnych, następnie usług związanych z dostawą energii, gazu, ciepła, wody oraz wywozu nieczystości (27 472), a następnie usług finansowych (20 177) (tab. 1) $)^{19}$.

Tabela 1. Liczba porad udzielonych konsumentom przez powiatowych (miejskich) rzeczników konsumentów w kategorii wybranych usług w latach 2011-2016

\begin{tabular}{|l|c|c|c|c|c|c|}
\hline Wyszczególnienie & \multicolumn{5}{|c|}{ Rok } \\
\cline { 2 - 7 } & 2011 & 2012 & 2013 & 2014 & 2015 & 2016 \\
\hline Usługi telekomunikacyjne & 44411 & 51487 & 53542 & 53280 & 54874 & 54646 \\
Usługi związane z dostawą energii, & 10118 & 15375 & 15927 & 21720 & 27969 & 27472 \\
gazu, ciepła, wody oraz wywóz & & & & & & \\
nieczystości & & & & & & \\
Usługi finansowe & 19417 & 24126 & 23251 & 23089 & 22078 & 20177 \\
Usługi ubezpieczeniowe & 12258 & 11965 & 13264 & 19261 & 14915 & 16077 \\
Usługi windykacyjne & 7784 & 8528 & 9818 & 10767 & 13000 & 12280 \\
\hline
\end{tabular}

Źródło: Działania powiatowych i miejskich rzeczników konsumentów w roku 2016. Urząd Ochrony Konkurencji i Konsumentów, Departament Ochrony Interesów Konsumentów. Warszawa, grudzień 2017.

Problemy związane $\mathrm{z}$ usługami telekomunikacyjnymi wiązały się m.in. z: trudnościami z odstapieniem od umowy zawartej $\mathrm{z}$ operatorem telefonii stacjonarnej, komórkowej lub $\mathrm{z}$ operatorami telewizji kablowej; wybiórczymi informacjami o warunkach ofert promocyjnych; nieprawidłowo naliczanym abonamentem, nakładaniem na konsumentów kar umownych. Jak podkreślali rzecznicy, działania operatorów, podczas których występowały naruszenia praw konsumentów, związane były przede wszystkim z wykorzystywaniem środków porozumiewania się na odległość, poprzez kontakt telefoniczny z konsumentem, bądź poza lokalem przedsiębiorstwa. Drugą co do liczebności kategorię spraw dotyczących usług stanowiły skargi na usługi związane $\mathrm{z}$ dostawą energii, gazu, ciepła, wody oraz wywóz nieczystości, które wskazywały m.in. na: nieprawidłowości związane $\mathrm{z}$ zawieraniem umów; zawyżaniem rachunków. Największy problem, jak wynika ze sprawozdania rzeczników konsumentów stanowi zawieranie umów o dostawę energii w mieszkaniach konsumentów przez nowe firmy, których przedstawiciele podszywają się pod aktualnych dostawców usług, jak również nieinformowanie o dodatkowych opłatach, które ponosić będą w stosunku do innej firmy za dystrybucję energii elektrycznej. Kolejna grupa skarg (trzecia pod względem liczebności) najczęściej składanych przez konsumentów dotyczyła usług finansowych. Skargi związane były m.in. z: utrudnianiem realizacji uprawnienia do odstapienia od umowy o kredyt konsumencki; wprowadzaniem w błąd lub nierzetelnym informowaniem konsumenta co do wysokości oprocentowania i opłat; zaniedbaniem w dostarczaniu klientom informacji o zmianach umów i regulaminów czy też oferowaniem przez banki skomplikowanych produktów ubezpieczeniowych $\mathrm{z}$ funduszami kapitałowymi. Skargi konsumentów dotyczyły często także usług ubezpieczeniowych. W tym przypadku były one związane m.in. z: odmową wypłaty odszkodowań z zakresu ubezpieczeń komunikacyjnych; zaniżaniem wartości szkody czy też odmową uznania

${ }^{19}$ Działania powiatowych i miejskich rzeczników konsumentów w roku 2016. Urząd Ochrony Konkurencji i Konsumentów, Departament Ochrony Interesów Konsumentów. Warszawa, grudzień 2017. 
roszczeń o odszkodowanie w całości lub w części. Następna grupa skarg najczęściej zgłaszanych przez konsumentów dotyczyła głównie agresywnych działań firm windykacyjnych ${ }^{20}$.

Warto więc, w kontekście przedstawionych tych wybranych skarg wpływających do powiatowych (miejskich) rzeczników konsumentów, podkreślić, że istotna jest kwestia znajomości praw konsumentów. Znajomość tych praw jest bowiem integralnym elementem kompetencji współczesnego konsumenta, a niestety jak wskazują wyniki badań, często nadal konsumenci nie są świadomi praw, nie znają sposobów dochodzenia roszczeń, ani też instytucji i organizacji, które mogą im pomóc ${ }^{21}$. Ponadto, jak podkreśla B. Czerwiński, należy pamiętać, że $\mathrm{z}$ jednej strony następują intensywne zmiany technologiczne, koncentrujące się w znacznym stopniu na rozwoju sieci Internet. Z drugiej zaś następuja zmiany struktury demograficznej prowadzące do starzenia się społeczeństwa, co powoduje, że niezbędne staje się położenie większego nacisku w dotychczasowej aktywności przedsiębiorstw na grupe starszych konsumentów ${ }^{22}$. Jednocześnie Urząd Ochrony Konkurencji i Konsumentów zwraca uwagę, że sprzedawcy wykorzystują zaufanie, jakim darzą ich seniorzy. Handlowcy wykorzystują ich łatwowierność i nieznajomość prawa konsumenckiego, stąd też seniorów powinno się szczególnie chronić przed nieuczciwymi praktykami rynkowymi. Wśród nich wymienia się m.in.: nieujawnianie handlowego celu pokazu w trakcie zapraszania (np. zaproszenie na bezpłatne badanie medyczne); wprowadzanie w błąd co do właściwości produktów (np. uczestnikom pokazu wmawia się, że pościel ma własności rehabilitacyjne); stosowanie niedopuszczalnego nacisku w trakcie zawierania umów (np. odwoływanie się do odpowiedzialności za stan zdrowia członków rodziny); niedoręczanie dokumentów dotyczących zawartej umowy (np. nieprzekazywanie wzoru formularza o odstapieniu od umowy); uniemożliwianie kontaktu ze sprzedawcą (np. podawanie fałszywych adresów poczty elektronicznej lub brak reakcji na telefony i emaile $)^{23}$. Stąd też tym bardziej jest istotne przygotowanie kolejnych zmian w regulacjach prawnych, mających na celu zwiększenie ochrony konsumentów.

\section{Pozasądowe rozwiązywanie sporów pomiędzy konsumentami a przedsiębiorcami i przykłady takich dzialań}

W sytuacji, gdy przedsiębiorca nie zgadza się z roszczeniem konsumenta i odmawia uznania reklamacji, a konsument nie chce przenosić tego sporu na drogę sądową, wówczas może skorzystać z innych sposobów wyjścia z konfliktu. Za zgodą obydwu stron neutralna osoba trzecia (niezależna instytucja) - np. mediator, koncyliator albo arbiter - pośredniczy w kontaktach między przedsiębiorcą a konsumentem. Stąd też wśród metody rozwiązywania sporów bez udziału sądu wyróżnia się:

- umożliwienie zbliżenia stanowisk stron, np. poprzez mediację; strony samodzielnie wypracowują ugodowe, najkorzystniejsze dla nich rozwiązanie, a wybrany przez

\footnotetext{
${ }^{20}$ Ibidem.

${ }^{21}$ Por. szerzej: A. Dąbrowska i in., Kompetencje konsumentów, innowacyjne zachowania, zrównoważona konsumpcja. PWE, Warszawa 2015, s. 148-173.

${ }^{22}$ B. Czerwiński B., Osoby starsze wobec innowacyjnych form świadczenia usług ubezpieczeniowych, Zeszyty Naukowe Polityki Europejskie, Finanse i Marketing, 14(63)/2015, s. 19.

${ }^{23}$ Por. szerzej: https://uokik.gov.pl/aktualnosci.php?news_id=14138 [dostęp: 5.05.2018].
} 
nich mediator jedynie ułatwia kontakt i wspiera ich w komunikacji — nie ustala kto ma rację i nie narzuca własnych rozwiązań;

- zaproponowanie rozwiązania sporu, np. poprzez koncyliację; pomoc neutralnej osoby trzeciej polega na zapoznaniu się z problemem, a następnie zaproponowaniu konkretnego sposobu rozwiązania sporu; strony sporu mają prawo nie zgodzić się z tą propozycją lub nie zastosować się do niej;

- rozstrzygnięcie sporu i narzucenie stronom jego rozwiązania, np. w ramach arbitrażu (sąd polubowny); dochodzi do rozstrzygnięcia sporu przez arbitra lub kilku arbitrów, niewielka jest natomiast aktywność stron w wypracowaniu rozwiązania; wydawany jest wyrok, przyznający rację jednej ze stron i mający taką samą moc prawną, jak wyrok sądu powszechnego, a strony mają obowiązek poddania się temu rozstrzygnięciu ${ }^{24}$.

Porównanie mediacji i arbitrażu według UOKiK przedstawia tabela 2.

Tabela 2. Porównanie mediacji i arbitrażu

\begin{tabular}{|l|l|l|}
\hline Wyszczególnienie & Mediacja & Arbitraż \\
\hline Kto decyduje & Strony & arbiter \\
Osoba rozjemcy & Mediator & arbiter \\
Podstawa & umowa o mediację (nie musi być pisemna) & zapis na sąd (musi być pisemny) \\
Postępowanie & nieformalne, elastyczne & większy formalizm \\
Charakter rozwiązania & Ugoda & wyrok \\
Moc rozwiązania & niewiążąca & wiążąca \\
Rezultat & sukces obydwu stron & sukces/przegrana \\
\hline
\end{tabular}

${ }^{1}$ Ugoda zawarta przed mediatorem, po jej zatwierdzeniu przez sąd, ma moc prawną ugody zawartej przed sądem, a ugoda zawarta przed mediatorem, którą zatwierdzono przez nadanie jej klauzuli wykonalności, jest tytułem wykonawczym.

Źródło: http://polubowne.uokik.gov.pl/pytania-i-odpowiedzi,6,pl.html [dostęp: 5.05.2018]

Pozasądowe rozwiązywanie sporów, nazywane również polubownym postępowaniem prowadzonym w sporach pomiędzy konsumentami a przedsiębiorcami określane jest w skrócie jako ADR (ang. Alternative Dispute Resolution). Jest to procedura wprowadzona ustawą $\mathrm{z}$ dnia 23 września 2016 r. o pozasądowym rozwiązywaniu sporów konsumenckich ${ }^{25}$. Jest ona szybsza, zazwyczaj bezpłatna i znacznie mniej sformalizowana niż postępowanie przed sądem powszechnym. Żeby wszcząć postępowanie, muszą zostać spełnione trzy warunki: konsument zgłosił przedsiębiorcy reklamację; spór pomiędzy konsumentem a przedsiębiorcą nie został zakończony, a także przedsiębiorca przy odmowie uznania reklamacji nie zaznaczył, że nie wyraża zgody na pozasądowe rozwiązanie sporu konsumenckiego.

Z systemu pozasądowego rozwiązywania sporów konsumenckich zostały wyłączone następujące branże:

- usługi niemające charakteru gospodarczego, świadczone w interesie ogólnym (np. usługi z zakresu transportu publicznego, gospodarki odpadami, dostarczania wody);

- usługi zdrowotne świadczone przez pracowników służby zdrowia na rzecz pacjentów w celu oceny, utrzymania lub poprawy ich stanu zdrowia;

\footnotetext{
${ }^{24}$ Por. szerzej: http://polubowne.uokik.gov.pl/

${ }^{25}$ Dz.U. z 2016 r. poz. 1823.
} 
- $\quad$ usługi edukacyjne lub kształcenia ustawicznego świadczone przez publiczne szkoły lub placówki oraz publiczne szkoły wyższe ${ }^{26}$.

Spory konsumenckie mogą rozwiązywać podmioty uprawnione wpisane do Rejestru prowadzonego przez Prezesa UOKiK. Uprawnione podmioty muszą działać według określonych zasad i spełniać określone wymagania. Specjalizują się one w sprawach typowych dla danej branży, np. finansowej, telekomunikacyjnej czy energetycznej. Ponadto dane zawarte w rejestrze oraz wszelkie ich zmiany przekazywane są do Komisji Europejskiej, która publikuje wykaz podmiotów prowadzących postępowania pozasądowego rozwiązywania sporów konsumenckich zgłoszonych jej przez państwa członkowskie UE na platformie ODR (ODR - Online Dispute Resolution $)^{27}$.

Odnosząc się poszczególnych sektorów usług, publiczne podmioty sektorowe zajmują się postępowaniem pozasądowym w odniesieniu do następujących rodzajów usług:

- usługi finansowe - Rzecznik Finansowy i Sąd Polubowny przy Komisji Nadzoru Finansowego;

- usługi telekomunikacyjne i pocztowe - Prezes Urzędu Komunikacji Elektronicznej;

- usługi energetyczne - Koordynator do spraw negocjacji działający przy Prezesie Urzędu Regulacji Energetyki;

- usługi transportowe - Rzecznik Praw Pasażera Kolei działający przy Prezesie Urzędu Transportu Kolejowego.

Z kolei niepubliczne podmioty sektorowe (utworzone przez przedsiębiorców z danej branży) są upoważnione do rozwiązywania sporów w przypadku następujących usług:

- usługi finansowe - Bankowy Arbitraż Konsumencki przy Związku Banków Polskich;

- usługi transportowe - Stowarzyszenie Praw Pasażerów Przyjazne Latanie;

- $\quad$ sprzedaż usług (a także towarów) przez internet - Izba Gospodarki Elektronicznej.

Działanie tych podmiotów uzupełnia Inspekcja Handlowa. Zajmuje się ona sprawami związanymi ze sprzedażą towarów i świadczeniem usług, dla których nie powstały wyspecjalizowane instytucje polubownego rozwiązywania sporów, takich jak:

- usługi turystyczne;

- usługi deweloperskie;

- usługi edukacyjne niepubliczne;

- usługi remontowo-budowlane;

- inne branże, w których nie powstały wyspecjalizowane podmioty uprawnione.

Należy podkreślić, że w odniesieniu do pozasądowego rozwiązywania sporów konsumenckich, Inspekcja Handlowa funkcjonuje na mocy Rozporządzenia Prezesa Rady Ministrów z dnia 17 maja 2017 r. w sprawie regulaminu organizacji i działania Inspekcji Handlowej w zakresie pozasądowego rozwiązywania sporów konsumenckich $^{28}$.

Analizując wybrane sprawozdania tych instytucji, m.in. warto podkreślić, że w 2017 roku wpłynęło do Rzecznika Finansowego łącznie 3741 wniosków o rozwiązanie

\footnotetext{
${ }^{26}$ Por. szerzej: http://polubowne.uokik.gov.pl/pytania-i-odpowiedzi,6,pl.html

${ }^{27}$ Platforma ODR jest dostępna pod adresem:

https://ec.europa.eu/consumers/odr/main/index.cfm?event=main.home.show\&lng=PL

${ }^{28}$ Dz.U. z 2017 r. poz. 1014.
} 
sporu klienta rynku finansowego z podmiotem rynku finansowego (1347 wniosków wpłynęło więcej w 2017 r. w porównaniu do 2016 r., co stanowi wzrost w porównaniu do 2016 r o 56\%). Rzecznik wszczął 2564 pozasądowych postępowań mających na celu rozwiązanie sporu klienta rynku finansowego $\mathrm{z}$ podmiotem rynku finansowego. Najwięcej spraw dotyczyło spraw ubezpieczeniowych (2251), następnie bankowokapitałowych (1490) oraz kredytów walutowych $(1123)^{29}$.

Z kolei do Prezesa UKE w 2017 r. wpłynęło 1559 wniosków o wszczęcie postępowania ADR, 45\% postępowań zakończono na korzyść konsumenta. Odnotowano następujące najczęstsze problemy prowadzące do sporów konsumenckich: nieuczciwe praktyki przedstawicieli handlowych (wprowadzanie abonentów w błąd przy zawieraniu umowy); SMS-y Premium Rate i związany z tym sposób aktywacji usług; zmiana warunków umowy niezgodnie z ustaleniami z rozmowy telefonicznej czy też rozliczenia (faktury/opłaty). W przypadku usług pocztowych w 2017 r. do UKE wpłynęły tylko 144 wnioski o wszczęcie postępowania ADR. Problemy prowadzące do sporów konsumenckich: brak możliwości zadeklarowania wartości przesyłki lub ubezpieczenia; brak analizy warunków regulaminu świadczenia usługi pocztowej czy też brak sporządzenia protokołu szkody ${ }^{30}$.

Konsumenci mogą wykorzystać również drogę rozwiązywania sporów oferowana przez sieć stałych sądów polubownych przy Wojewódzkich Inspektoratach Inspekcji Handlowej. Obecnie jest ich 16 oraz 15 ośrodków zamiejscowych. Wydane zostało w tym zakresie Rozporządzenie Ministra Sprawiedliwości z dnia 6 lipca 2017 r. w sprawie określenia regulaminu organizacji i działania stałych sądów polubownych przy wojewódzkich inspektorach inspekcji handlowej ${ }^{31}$. Należy podkreślić, że wyroki stałego sądu polubownego, a także ugoda przed nim zawarta mają taką samą moc jak wyrok sądów powszechnych. Jednak zgodę na stały sąd polubowny muszą wyrazić obie strony, spory te mogą dotyczyć tylko sporów między konsumentami i przedsiębiorcami, wynikających z umów sprzedaży i świadczenia usług (tzw. praw majątkowych). Do stałych sądów polubownych przy Wojewódzkich Inspektorach Inspekcji Handlowej, można kierować sprawy, w których wartość przedmiotu sporu nie przekracza 10 tys. zł., za wyjątkiem Stałego Sądu Polubownego działającego przy WIIH w Warszawie, który rozpatruje sprawy bez względu na wartość przedmiotu sporu. Do stałego sądu polubownego sprawę może wnieść nie tylko konsument, ale także przedsiębiorca, organizacja konsumencka, miejski (powiatowy) rzecznik konsumentów. Każda ze stron może mieć pełnomocnika, którym nie musi być adwokat czy też radca prawny. Rozprawy są jawne, sporządza się z nich protokół. Wyrok zapada większością głosów i w ciagu 14 dni od ogłoszenia przesyła się go stronom wraz z pisemnym uzasadnieniem.

\footnotetext{
${ }^{29}$ Sprawozdanie z działalności Rzecznika Finansowego za 2017 r. oraz uwagi o stanie przestrzegania prawa i interesów klientów podmiotów rynku finansowego.

https://rf.gov.pl/files/22778_5316_Sprawozdanie_Rzecznika_Finansowego_za_2017_r_pdf [dostęp: 4.05.2018].

${ }^{30}$ Sprawozdanie z działalności Prezesa Urzędu Komunikacji Elektronicznej w zakresie pozasądowego rozwiązywania sporów konsumenckich (ADR) w 2017 r. Urząd Komunikacji Elektronicznej, Warszawa 2018. Internet: https://uke.gov.pl/akt/sprawozdanie-z-dzialalnosci-prezesa-uke-w-zakresie-pozasadowegorozwiazywania-sporow-konsumenckich-adr-w-2017-r-,70.html [dostęp: 10.05.2018].

${ }^{31}$ Dz.U. z 2017 r poz. 1356.
} 
Sąd Polubowny funkcjonuje również przy Komisji Nadzoru Finansowego (KNF). Został on powołany na podstawie ustawy z dnia 21 lipca 2006 r. o nadzorze nad rynkiem finansowym $^{32} \mathrm{w}$ celu rozpatrywania sporów między uczestnikami rynku finansowego. Sąd ten może prowadzić również postępowania $\mathrm{W}$ sprawie pozasądowego rozwiązywania sporów konsumenckich na zasadach i w trybie określonych w ustawie $\mathrm{z}$ dnia 23 września 2016 r. o pozasądowym rozwiązywaniu sporów konsumenckich oraz regulaminie Sądu Polubownego.

W 2017 roku do Sądu Polubownego przy KNF wpłynęło łącznie 2977 wniosków o polubowne rozwiązanie sporu. Spośród wszystkich złożonych do Sądu Polubownego tylko wniosków 65 dotyczyło sporu, gdzie odbiorcą usług finansowych nie był konsument. Wnioski te dotyczyły najczęściej sektora ubezpieczeniowego (ponad 82\% spraw) oraz sektora bankowego (blisko 17\% spraw). W toku postępowań przed Sądem Polubownym najczęściej podnoszonymi problemami, które prowadziły do sporów konsumenckich były: odmowa lub częściowa odmowa wypłaty odszkodowania lub świadczenia $\mathrm{z}$ umowy ubezpieczenia, stosowanie niedozwolonych postanowień umownych (w szczególności w przypadku umów ubezpieczenia na życie $\mathrm{z}$ ubezpieczeniowym funduszem kapitałowym oraz umów kredytu indeksowanych/denominowanych do walut obcych), stosowanie niedozwolonych praktyk rynkowych (w szczególności na etapie kontraktowym, obejmujące nierzetelne wypełnianie obowiązków informacyjnych).

\section{Inne możliwości dochodzenia roszczeń przez konsumentów}

Warto podkreślić, że konsument oprócz wspomnianych form polubownych, a także sądownictwa powszechnego, może skorzystać $\mathrm{z}$ przepisów o postępowaniu uproszczonym, które zostały ujęte $\mathrm{w}$ art. $505^{1}$ ustawy z dnia 17 listopada 1964 r. Kodeks postępowania cywilnego ${ }^{33}$. Przepisy te stosuje się m.in. w następujących sprawach należących do właściwości sądów rejonowych: o roszczenia wynikające z umów, jeżeli wartość przedmiotu sporu nie przekracza dwudziestu tysięcy złotych, a w sprawach o roszczenia wynikające z rękojmi, gwarancji jakości lub z niezgodności rzeczy sprzedanej konsumentowi z umową, jeżeli wartość przedmiotu umowy nie przekracza tej kwoty. W tym celu wydane zostało również Rozporządzenie Ministra Sprawiedliwości z dnia 5 kwietnia 2012 r. w sprawie określenia wzorów i sposobu udostępniania urzędowych formularzy pism procesowych w postępowaniu cywilnym ${ }^{34}$.

Interesującym rozwiązaniem dla konsumentów jest również zbiorowe dochodzenie roszczeń. Jest to mechanizm procesowy umożliwiający łączenie wielu podobnych roszczeń prawnych i dochodzenie ich w jednym postępowaniu sądowym ze względu na ekonomię procesową lub skuteczność egzekwowania prawa. W Polsce w tym zakresie obowiązuje ustawa z dnia 17 grudnia 2009 r. o dochodzeniu roszczeń w postępowaniu grupowym $^{35}$. Ten akt prawny normuje sądowe postępowanie cywilne $\mathrm{w}$ sprawach, w których są dochodzone roszczenia jednego rodzaju, oparte na tej samej lub takiej samej podstawie faktycznej co najmniej 10 osób (postępowanie grupowe). Ustawa ma

\footnotetext{
${ }^{32}$ Dz.U. z 2018 r. poz. 621 z późn. zm.

${ }^{33}$ Tekst jedn.: Dz.U. z 2018 r. poz. 155.

${ }^{34}$ Tekst jedn.: Dz.U. z 2015 r. poz. 723 z późn. zm.

${ }^{35}$ Tekst jedn.: Dz.U. z 2018 r. poz. 573.
} 
zastosowanie $\mathrm{W}$ sprawach o roszczenia $\mathrm{z}$ tytułu odpowiedzialności za szkodę wyrządzoną przez produkt niebezpieczny, z tytułu czynów niedozwolonych, z tytułu odpowiedzialności za niewykonanie lub nienależyte wykonanie zobowiązania umownego lub $\mathrm{z}$ tytułu bezpodstawnego wzbogacenia, a w odniesieniu do roszczeń o ochronę konsumentów także w innych sprawach. W postępowaniu grupowym jest wyłączone dochodzenie roszczeń o ochronę dóbr osobistych, z wyjątkiem roszczeń wynikających $\mathrm{z}$ uszkodzenia ciała lub wywołania rozstroju zdrowia, w tym roszczeń przysługujących najbliższym członkom rodziny poszkodowanego, zmarłego wskutek uszkodzenia ciała lub wywołania rozstroju zdrowia. Ponadto należy pamiętać, że występowanie grupowe w sprawach o roszczenia pieniężne jest dopuszczalne tylko wtedy, gdy wysokość roszczenia każdego członka grupy została ujednolicona poprzez zrównanie wysokości roszczenia dochodzonego przez członków grupy lub podgrupy, przy czym ujednolicenie wysokości roszczeń może nastąpić w podgrupach, liczących co najmniej 2 osoby.

Podkreślić więc należy, że zbiorowe dochodzenie roszczeń ułatwia dostęp do wymiaru sprawiedliwości, w szczególności w przypadkach gdy wartość szkody jednostkowej jest tak niska, że podmiot potencjalnie występujący z roszczeniem nie uznałby, że warto dochodzić jego zaspokojenia. Przede wszystkim wzmacnia jednakże siłę negocjacyjną tych podmiotów i przyczynia się do skutecznego zarządzania wymiarem sprawiedliwości poprzez uniknięcie licznych postępowań wynikających z tego samego naruszenia prawa.

\section{Podsumowanie}

Reasumując, należy podkreślić, że dynamicznie zmieniająca się sfera naszej codziennej konsumenckiej aktywności, jaką jest konsumpcja usług, zasługuje na jej ciągłe monitorowanie również w aspekcie przestrzegania praw konsumentów. Dokonane analizy wskazują, że nie zawsze jednak przestrzegane są prawa konsumentów na rynku usług. Stąd też, z jednej więc strony, zarówno istnienie wybranych regulacji prawnych, jak też i różnych instytucji i organizacji pozarządowych zajmujących się ochroną konsumentów na rynku usług, przyczynia się do zwiększenia poziomu tej ochrony i ewentualnej możliwości dochodzenia roszczeń przez konsumentów. Z drugiej natomiast, dla pełnej ochrony konsumentów na rynku usług w Polsce nadal niezbędne jest prowadzenie zarówno edukacji konsumenckiej w celu zwiększenia świadomości konsumentów z zakresu praw im przysługujących w danym obszarze usług, jak też i konieczność kształcenia się w zakresie ochrony konsumentów świadczących usługi. Ponadto, pomimo zwiększającego się zainteresowania polubownym sposobem rozwiązywania sporów, nadal istnieje konieczność prowadzenia przez różne instytucje i organizacje działań informacyjno-edukacyjnych również w tym zakresie. Przyczyni się to do wzrostu świadomości istnienia możliwości wykorzystania tego sposobu rozwiązywania sporów, zarówno wśród przedsiębiorców, jak i konsumentów.

\section{Bibliografia}

Czerwiński B., Osoby starsze wobec innowacyjnych form świadczenia usług ubezpieczeniowych, Zeszyty Naukowe Polityki Europejskie, Finanse i Marketing, 14(63)/2015. 
Dąbrowska A., Bylok F., Janoś-Kresło M., Kiełczewski D., Ozimek I., Kompetencje konsumentów, innowacyjne zachowania, zrównoważona konsumpcja. PWE, Warszawa 2015.

Działania powiatowych i miejskich rzeczników konsumentów w roku 2016. Urząd Ochrony

Konkurencji i Konsumentów, Departament Ochrony Interesów Konsumentów. Warszawa, grudzień 2017. https://uokik.gov.pl/download.php?plik=21112 [dostęp: 29.04.2018].

Komunikat Komisji do Parlamentu Europejskiego, Rady, Europejskiego Komitetu EkonomicznoSpołecznego i Komitetu Regionów, „W kierunku europejskich horyzontalnych ram w zakresie zbiorowego dochodzenia roszczeń". Komisja Europejska, Strasburg, 11.06.3013 r., COM(2013), 401 final.

Sprawozdanie z działalności Wydziału Pozasądowego Rozwiązywania Sporów w Biurze Rzecznika Finansowego za $2017 \quad$ r. Warszawa, kwiecień 2018. https://zbp.pl/public/repozytorium/dla_konsumentow/arbiter_bankowy/sprawozdania/SPRAWZO DANIE_BAK_2017.pdf [dostęp: 4.05.2018].

Sprawozdanie z działalności Rzecznika Finansowego za 2017 r. oraz uwagi o stanie przestrzegania prawa i interesów klientów podmiotów rynku finansowego. https://rf.gov.pl/files/22778_5316_Sprawozdanie_Rzecznika_Finansowego_za_2017_r_.pdf [dostęp: 4.05.2018].

Sprawozdanie $\mathrm{z}$ działalności Sądu Polubownego przy KNF w zakresie pozasądowego $\begin{array}{llllll}\text { rozwiązywania sporów } & \text { konsumenckich } & \text { w } & 2017 & \text { roku }\end{array}$ file:///C:/Users/WNE/Documents/Usługi/Sprawozdanie\%20z\%20działalności\%20SP\%20przy\%20 KNF\%20w\%20zakresie\%20pozasądowego\%20rozwiązywania\%20sporów\%20konsumenckich_61 603.pdf_[dostęp: 4.05.2018].

Sprawozdanie z działalności Sądu Polubownego przy Komisji Nadzoru Finansowego w 2017 roku.https://www.knf.gov.pl/knf/pl/komponenty/img/SPRAWOZDANIE\%20SP_KNF_12_61530. 04_61530.2018_61530.pdf [dostęp: 29.04.2018].

Stoma M., Modele i metody pomiaru jakości usług. Q\&R Polska Sp. z o.o., Lublin 2012.

Ustawa z dnia 16 kwietnia 1993 r. o zwalczaniu nieuczciwej konkurencji. Tekst jedn.: Dz.U. z 2003 r. Nr 153, poz. 1503 z późn. zm.

Ustawa z dnia 16 lutego 2007 r. o ochronie konkurencji i konsumentów. Tekst jedn.: Dz.U. z 2018 r. poz. 798 .

Ustawa z dnia 23 sierpnia $2007 \mathrm{r}$. o przeciwdziałaniu nieuczciwym praktykom rynkowym. Tekst jedn.: Dz.U. z 2016 r. poz. 3 z późn. zm.

Ustawa z dnia 30 maja 2014 r. o prawach konsumenta Dz.U. z 2014 r. poz. 827 z późn. zm.

Ustawa z dnia 6 marca 2018 r. o zasadach uczestnictwa przedsiębiorców zagranicznych i innych osób zagranicznych w obrocie gospodarczym na terytorium Rzeczypospolitej Polskiej. Dz.U. z 2018 r. poz. 649

Ustawa z dnia 6 marca 2018 r. Prawo przedsiębiorców. Dz.U. z 2018 r. poz. 646.

Ustawa z dnia 9 maja 2014 r. o informowaniu o cenach towarów i usług Dz.U. z 2014 r. poz. 915 z późn. zm.

Wawrzyniak A., Modelowanie wieloagentowe jako narzędzie do badania zachowania konsumentów, Zeszyty Naukowe Polityki Europejskie, Finanse i Marketing, 14(63)/2015.

\section{Summary}

The purpose of this article is to present legal regulations which included the issues of consumer protection on the market of selected services and ways of pursuing claims by consumers in case of rights violation. The research consist of secondary data analysis i.e. legal acts, reports of selected sector entities (public and non-public) in terms of out-of-court dispute resolution between the consumer and the entrepreneur resulting from the contract concluded with the consumer. The results of the data analysis show that consumers' rights are not always respected on the services market. Moreover, despite the growing interest in the amicable way of disputes resolving, there is 
still a need to carry out information and education activities in this area provided by various institutions and organizations. This will increase the awareness of existence the possibility of using this method of dispute resolution both among entrepreneurs and consumers.

Keywords: consumer protection, services market, legal regulations, consumer claim pursuing, out-of-court resolution of consumers' disputes.

Informacje o autorze:

Prof. dr hab. Irena Ozimek

Katedra Polityki Europejskiej i Marketingu

Wydział Nauk Ekonomicznych

Szkoła Główna Gospodarstwa Wiejskiego

e-mail: irena_ozimek@sggw.pl 